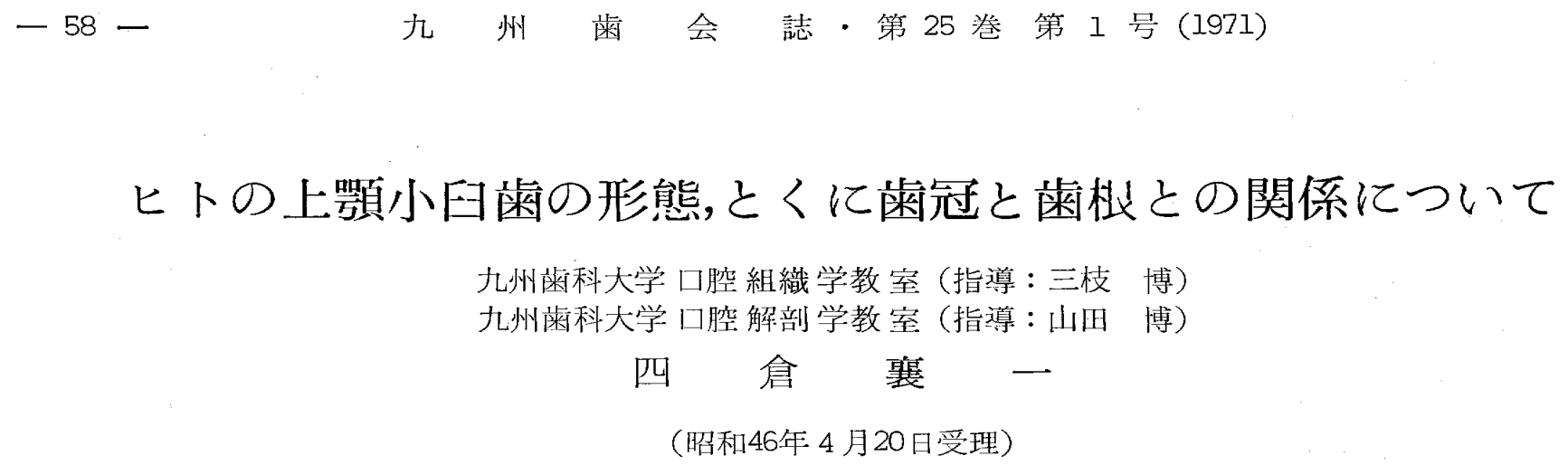

\title{
A STUDY ON THE MORPHOLOGY OF HUMAN MAXILLARY PREMOLARS WITH SPECIAL REFERENCE TO THE RELATION BETWEEN CROWN AND ROOT
}

\author{
By \\ Jyoichi YOTSUKURA \\ Department of Oral Histology (Director : Prof. Hiroshi SAEGUSA) \\ Department of Oral Anatomy (Director: Prof. Hiroshi YAMADA) \\ Kyushu Dental College, Kitakyushu, Japan
}

Human maxillary premolars were studied for their morphology with special regard to possible relation between individual parts of the teeth. Measurements were undertaken for the dimensions of the tooth crowns as well as for features of each part of occlusal surface of the crown, and results obtained were summarized as follows.

1) Dimension of Crowns

The 1st premolars were considerably larger than the 2nd premolars with every items of measurement, especially with breadth of the crowns. The retrogressive indices as obtained for these teeth indicated that the retrogression was most pronouced in crown length, followed by crown breadth and crown thickness in order.

2) Height of Buccal and Lingual Cusps

Cusps of both buccal and lingual sides of crown in the 1st premolar were higher than those in the 2nd premolar. Difference in the height of bilateral cusps was also greater in the 1st premolar than in the 2nd premolar where only a small difference was found.

3) Tooth Root

The majority of the 2nd premolars had single root while the 1st premolars frequently showed dual or triple roots, and even when the latter teeth were single-rooted, longitudinal grooves were often observed on both mesial and distal surfaces of the root suggesting an incomplete separation of the root. On the basis of phylogenetic consideration, the human premolars would seem to have undergone successive retrogression from triple-rcoted type down to dual-and single-rooted one.

4) Grooves of Occlusal Surface

Most of the 1st premolars had their typical pattern of groove well maintained, but the 2nd premolars had lost some of the sub-grooves and showed generally flat appearance. Such pictures of occlusal surface grooves were shown to be closely associated with the stages of root separation in individual teeth. 
5) Position of Cuspal Tips

In the 1st premolars, the buccial cusp tip was located much closer to distal side and the lingual cusp tip closer to mesial side, and gave an asymmetrie picture against the axial line connecting the bucco-lingual sides. On the other hand, both tips of buccal and lingual cusps in the 2nd premolars were located slightly close to mesial side and appeared quite different from the 1st premolars. Due to the well established stability of morphology found in the 1st premolars, one may be able to recognize a close association between the location of both cuspal tips and the courses of occlusal grooves. such association, however, could not be observed in the 2nd premolars where malformed morphology was much frequent. This would suggest that the 1st premolars represented the fundamental morphology of these kinds of teeth and the 2nd premolars were of their deviated form.

6) Comparison of Diagrams Showing Mean Values of Measurement of Cuspal Surface

A clear difference existed between the 1st and 2nd premolars in the location of buccal and lingual cusp tips by actual measurement in good agreement with macroscopical observation. when the 1st premolars were divided into 3 groups according to stages of ramification of the root for comparison, it was shown that their morphology resembled those of the 2nd premolars increasingly as the roots assumed characteristic form of the uniradicular tooth, and, on the other hand, as the ramification of roots became more apparent, so the buccal cusp tip was located increasingly toward distal side, eventually showing a markedly asymmetric picture agaist the bucco-lingual axis of the tooth.

The above study would seem to suggest that the 2nd premolars are undergoing a series of degenerative processes including diminution of dimension, simplification of the pattern of occlusal surface grooves, reduction of root ramification and symmetrical location of the bucco-lingual cusp tips as compared to the morphology of the 1st premolars.

上顎小曰幽は代生茵列に㧈ける最遠心端に位置し，特 に第二小臼歯は智歯书よば上顎側切歯に次いで退化的現 象を強く示している歯である。また乳歯とその後継永久 歯との間には前蒾部では比較的よく類似した形態が見ら れるのに，乳田歯とその後継歯である小曰雬とははなは だ類似性に之しい形態を示し，むしろ大四歯に近い形態 を示している。てのように上顎小曰歯の形態は比較形態 学的にあるいは系統発生学的にまた人類学的に非常に重 要な意義を含んでいるものと考えられる.

しかしながら上䪽小臼歯についての形態学的研究は現 在までののところ大部分が小曰歯北態の一部分について 調査されたもので，鹿井1）は咬合面裂溝形態について， 武久3) は米白人之日本人歯牙の人類学的形態比較のなか に执いて小田䎃形態に関して述へている。 また山田ら2 は小曰歯㐘冠の形態学研究を行なって扣り, 一般に歯冠 形態に関するものが多く, 菌根形態については主として
異常あるいは過剩歯根の報告例が抢もなあのである。そ の他特異的な研究としては酒井7）らの上額小巨歯に扝け るエナメル象牙境についての形態学的研究によって，人 の歯の系統発生学的な問題点を追求しょうとしているす のがある。

したがって上顎小曰歯の㐘冠抢よび歯根を全般的に総 合して，その形態的特徵を研究報告したものはほとんど ない。

そこで私は上顎小曰歯の歯冠および歯根の形態を調查 し，それぞれの形態的特徵を観察するととあに，功そ れらの各形質相互間の関連性についても検討を行なっ た。その結果上顎小曰菌に打ける基本的な形態を把握 し，さらには上顎の第一小曰歯之第二小曰菊間の北態的 変異が退化的要因によるあのであるか，あるいはおのお の独自の特徽的な形態によって表垷せられたところの差 か, といった点を追求するととを目的として本研究を行 なったむのである。また歯冠特に咬合面各部の計測值よ 
り得られた結果を基にして咬合面の模型図を作製し，第 一小曰䨑之第二小四霜之の晈合面外形の差異ならびに第 一小曰歯に抢ける㐘根の分肢状態に上る咬合面外形の相 異についても調查検討を試み，今回の研究目的を考察す る一助とした。

したがって以上のような観点に立脚して得られた結果 より，上顎小田歯汇関する意義ある形態学的な成果を得 たので報告する。

\section{調 查 資 料}

調査に用いた上顎小曰歯はすべて抜去歯牙で，その形 態の比較的明膫なものを選び，咬籷やカリエスなどで久 損が大なるむのは除外した。性別の判定は因難であるた め,すへて一括して処理した。調查歯数は第一小囦歯 3188本，第二小臼歯1060本である．たただし歯冠計測に 扔いてはそのうち咬粍その他で計測に不適当なものを除 外し，第一小歯225本，第二小曰霜240本について行な った。また咬合面各部の計測はさらにそのうちより厳選 して, 第一小四歯 122 本, 第二小曰歯40本について計測 を行なった。

\section{調查事項とその方法}

1 荬冠各部の計測

計測部位は菌冠の高さ，幅抢よび厚さについて行な い，そのうち高さについては煩側咬頭頂までの高さの他 に舌側咬頭頂までの高さもあわせて行なった。また咬合 面については図1に示す各部位の計測を行なった。

計測の方法は藤田5)の計測基準にしたがって行なった が, 必要に応じた万能投影器による1倍拡大像を模写し て行なった。

2 㐘冠の形態観察
図1上顎小曰菊㐘冠とくに咬合面の計測各部を示す 模型図

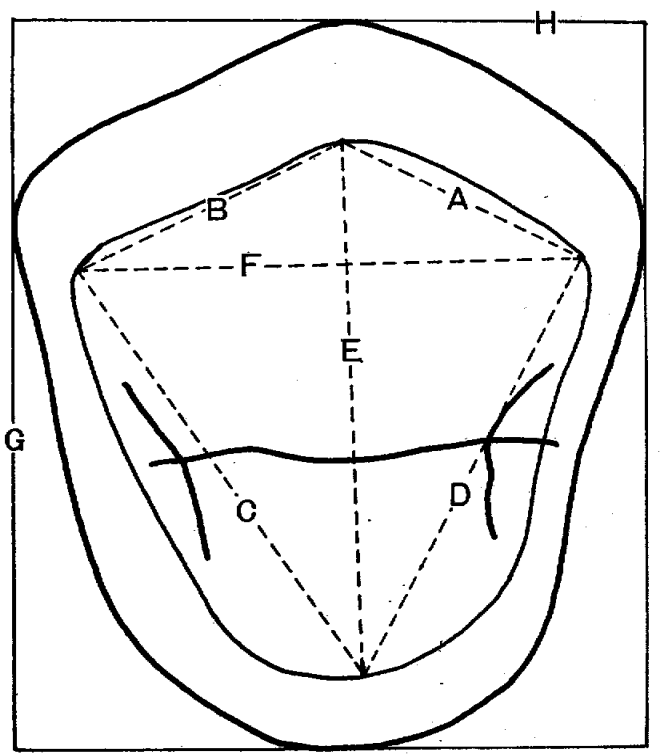

$\mathrm{A}$ 一頰側咬頭頂之近心煩側隈角部間の距離 B - " c遠心煩側隈角部間の距離 $\mathrm{C}$ 一舌側咬頭頂と

D - " 亡近心煩側隈角部間の距離

$\mathrm{E}$ 一頝側掞よび舌側咬頭頂間の距離 $\mathrm{F}$ 一近心扔よび遠心煩側郎角間の距離 $\mathrm{G}$ 一歯冠部の阫舌径

$\mathrm{H}$ 一歯冠部の近䞦心径

咬合面溝の形態に関してはてれを三型に分類した。す なわち図 2 に示すでとく上顎小臼歯に打ける最も基本的 な咬合面溝を第 I 型とし，以下それより変異した型態の ものを第型，第吕型とした。

頓側招よび舌側の咬頭頂の位置を肉眼的に観察し，そ れらか瀬舌的方向に走る歯冠中軸線上に位置しているも のを $\mathrm{C} と し ，$ 近心側に偏位しているものをM，遠心側に 偏位しているものをDとした。

表 I

上顎小白歯に拈ける料冠の大きさ

(単位 $m m$ )

\begin{tabular}{|c|c|c|c|c|c|c|c|c|}
\hline 歯 種 & \multicolumn{3}{|c|}{4} & \multicolumn{3}{|c|}{5} & & \multirow{2}{*}{5} \\
\hline 計測部位 & $\mathbf{N}$ & $\bar{x} \pm s \bar{x}$ & $\mathrm{U}^{2}$ & $\mathbf{N}$ & $\bar{x} \pm s \bar{x}$ & $\mathrm{U}^{2}$ & & \\
\hline 歯 冠 の 高 さ & 225 & $8.56 \pm 0.56$ & 0.31 & 240 & $7.60 \pm 0.60$ & 0.36 & 0.96 & $\bigcirc$ \\
\hline 来 冠 $\quad$ 幅 & 219 & 7. $36 \pm 0.40$ & 0.17 & 237 & $6.78 \pm 0.41$ & 0.17 & 0.58 & $\bigcirc$ \\
\hline 菡 冠 の 厚 さ & 225 & $9.62 \pm 0.52$ & 0.27 & 240 & $9.07 \pm 0.54$ & 0.29 & 0.55 & $\bigcirc$ \\
\hline 歯冠の幅と厚さの和 & 219 & $16.97 \pm 0.80$ & 0.65 & 237 & $15.81 \pm 0.85$ & 0.72 & 1.16 & 0 \\
\hline 霜冠 幅厚示 数 & 219 & $76.77 \pm 3.82$ & 14.66 & 237 & $74.55 \pm 3.99$ & 15.96 & 2.22 & 0 \\
\hline
\end{tabular}

○印は $1 \%$ の限度を以て有意差の認められるもの

$\triangle$ \印は $5 \%$ の限度を以て有意差の認められるもの 
3 蒾根の形態推察

歯根数について 2 根分忮の場合，歯根全長の $1 / 2$ 以下 にわたって分離しているものは完全分肢根とし，それ以 外の分岐状態のものを不完全分肢根とした。

次に歯根の近遠心両面に現われる縱啭については単根 歯における出現頻度のみを調查した。

\section{4 形質相互間の関連性}

上記の形質調查を行なったものについて，咬合面溝之 豄舌各咬頭頂の位置との関連性ならびに呚合面溝と歯根 数この関連性を検討した。すなわち以上の各項目間にお いて多項関連表を作製し，両者間には関連性はないとい う仮説に基ずいてその期待度数を出し， $\chi^{2}$ - Testによ って判定した。この場合 $5 \%$ の限度をもって有意差があ るとした。

\section{1 歯冠の計測成績}

歯冠各部の計測平均值は表 1 に示すように，すべての 計測項目にわたって第一小罒歯が第二小曰崡よりを大き く，また蒾冠幅厚示数も前者之同様 I\%以下の有意差を むって第一小印歯汃大きい，第二小四歯に比して，煩舌 径に対する近遠心径の縮少率が心っそう強くなっている ととを示している。

また歯冠の幅と厚さの和によって第一と第二小巨歯の 大きさを比較してみても, 明らかに第一小自歯が大き い.すな拈一般に㐘の大きさをみる場合，幅が大きい とその代償として厚さが小さいし，その反対の場合もあ るわ计であるが，第一小罒㐘之第二小臼歯の間ではその

いずれの径に执いても明らかに前者が大である。

かかる成績を他の日本人の計測成績（藤田恒17），上条 16)，藤田宗15)（と比較したととろ大差はないようであ る.

\section{2 咬合面溝の形態}

晈合面の溝の形態を図 2 のごとく 3 型に分類して，そ の出現頻度を調査したあのが表 2 である。すなわち第一 小臼藏では II 型が54. 9\%が最も多く，以下 I 型，III型の 順に少なくなっているのに対し，第二小臼㐘では亚型が 57. $9 \%$ で最も多く，以下而型，I型の順となっている. したがって咬合面溝の状態は第一小四歯よりも第二小臼 㐘が単調化していることが認められる.

3 咬合面に打る煩舌的中軸線に対する煩側咬頭頂 の位置

その肉眼的観察結果は表 3 に示すごとくで，第一小曰 歯はDすなおち中心よりも遠側に片寄っているものの 81. 3\%に対し，第二小四歯では $6.98 \%$ できわめて少な く，中央に位置しているもが64.1\%と大部分である。乙 の点に执いても第一之第二小罒畨との間に差異が認めら れるようである。

図 2 上顎小曰歯咬合面の清型の分類

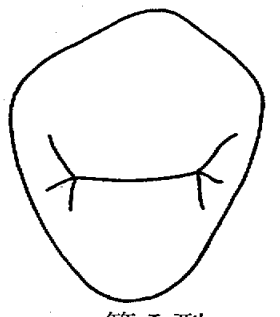

第 I 型

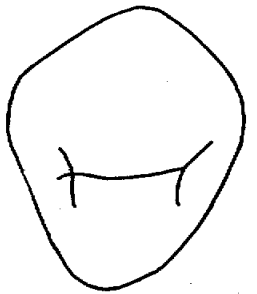

第 II 型

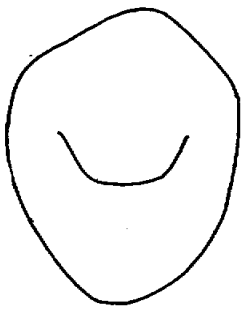

第而型

表 2 上薠小臼蒌の咬合面溝各形態の出現頻度

(\%)

\begin{tabular}{|c|c|c|c|c|c|c|c|}
\hline 溝 型 & & I 型 & & II 型 & & III 型 & \\
\hline 歯 別 & $\mathbf{N}$ & $M \pm m$ & $\mathbf{N}$ & $M \cdot \pm m$ & $\mathbf{N}$ & $\mathrm{M} \pm \mathrm{m}$ & \\
\hline$\underline{4}$ & 1096 & $34.4 \pm 0.84$ & 1750 & $54.9 \pm 0.88$ & 342 & $10.7 \pm 0.54$ & 3188 \\
\hline$\underline{5}$ & 44 & 4. $2 \pm 0.61$ & 402 & $37.9 \pm 1.49$ & 614 & $57.9 \pm 1.51$ & 1060 \\
\hline
\end{tabular}

表 3 上顎小曰釆の煩側咬頭頂の位置（\%）（肉眼的観祭）

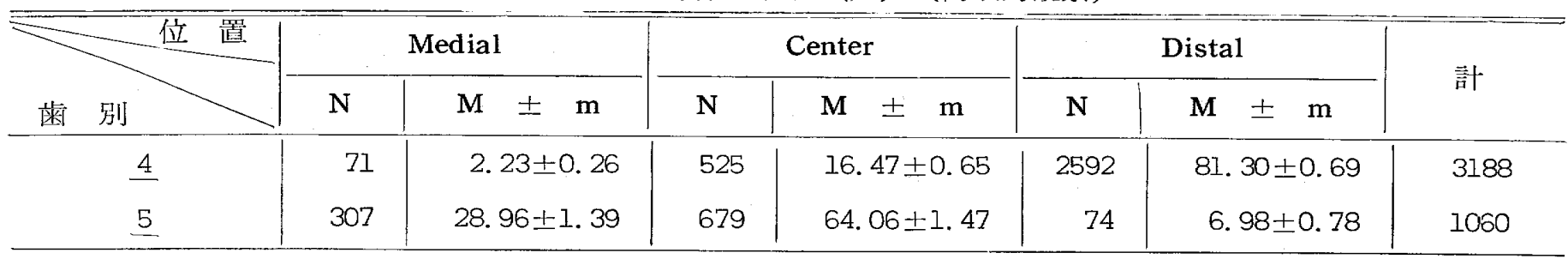




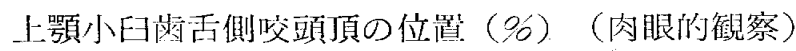

\begin{tabular}{|c|c|c|c|c|c|c|c|}
\hline \multirow{2}{*}{ 位 置 } & \multicolumn{2}{|c|}{ Medial } & \multicolumn{2}{|c|}{ Central } & \multicolumn{2}{|c|}{ Distal } & \multirow{2}{*}{ 計 } \\
\hline & $\mathrm{N}$ & $\mathbf{M} \pm \mathrm{m}$ & $\mathbf{N}$ & $\mathbf{M} \pm \mathbf{m}$ & $\mathrm{N}$ & $\mathrm{M} \pm \mathrm{m}$ & \\
\hline 4 & 2880 & $00.34 \pm 0.52$ & 308 & $9.66 \pm 0.52$ & 0 & & 3189 \\
\hline 5 & 727 & $68.58 \pm 1.42$ & 300 & 28. $30 \pm 1.38$ & 33 & 3. $11 \pm 0.53$ & 1060 \\
\hline
\end{tabular}

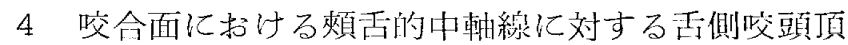
の位置

舌側咬頭頂の位置は表 4 亿示すごとく第一抢よび第二 小臼蒌之もに中央より近心 側に偏位しているものが多 く，特に第一小四歯では90.30\%で，邆心例に偏位してい るものは全く認められない：

したがって歯冠の煩舌的中軸線に対する䫶倒ならびに 舌側咬頭頂の位置的関係から考えて，第一小曰菊は頓倒 咬頭は遠心に，舌側咬頭は近心にかたよっており，中刺! 線に対して非対称性を示しているが，第二小罒菡は煩倒 咬頭は中央に，舌側咬頭は大部分が近心に，一部は中央 に位藏して招り，中軸線に対して比較的対称的な形態を しているということむいえる。

5 頓側咬頭と舌側咬頭との閒における高さの差の関 係

煩側咬頭の高さは歯冠の高さに相当するわけである. したがって，乙れに対して舌側咬頭の高さを計測し，両 者の差ならびに両者間の比をみるため咬頭高示数值を算 出して, 第一小曰歯之第二小四崡とを比較したところ著 明な差買が認められてた。
すなわち表らに示すでとく，頓側咬頭の高さは第一小

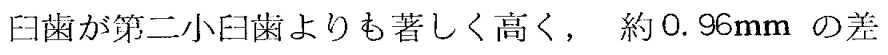
が認められるが, 舌側咬頭の高さは第一小臼歯で平均 $7.24 \mathrm{~mm}$ (最小值5.9〜最大值 $8.4 \mathrm{~mm}$ ), 第二小臼歯では 6. $86 \mathrm{~mm}$ （最小值 5.2 最大值 $8.5 \mathrm{~mm}$ ）とやはり第一小 四菌が $1 \%$ 以下の有意差で高いが, 煩側咬頭に㧍けるほ どの差は認められなかった。

このととは兩咬頭の高さの差について検討してみると よくわかるのであって，第一小四歯では差の平均が1. 32 $\mathrm{mm}$ ，第二小目藏では $0.74 \mathrm{~mm}$ で，画者の間には明らか な有意差が誌められ，また管頭高示数についてあ第一小 田菻では84.69，第二小臼歯では90.11で，雨者間には有 意差が認められたが，顂舌両咬頭間の高さの差は第二小 臼歯に抢いては第一小四歯よりもかなり接近している。

\section{6 霜根数}

小曰雬は単根, 二根分岐（賛側根と舌側根）あるいは まれに三根の場合（煩側根がさらに近遠心に分かれてい るあの）がある。ことに二根の場合は完全分岐根上不完 全分岐根の二群に分けられる. 表 6 はその出琴頻度示 したもので，第一小曰歯は単根か57.1\% 最も多く，二

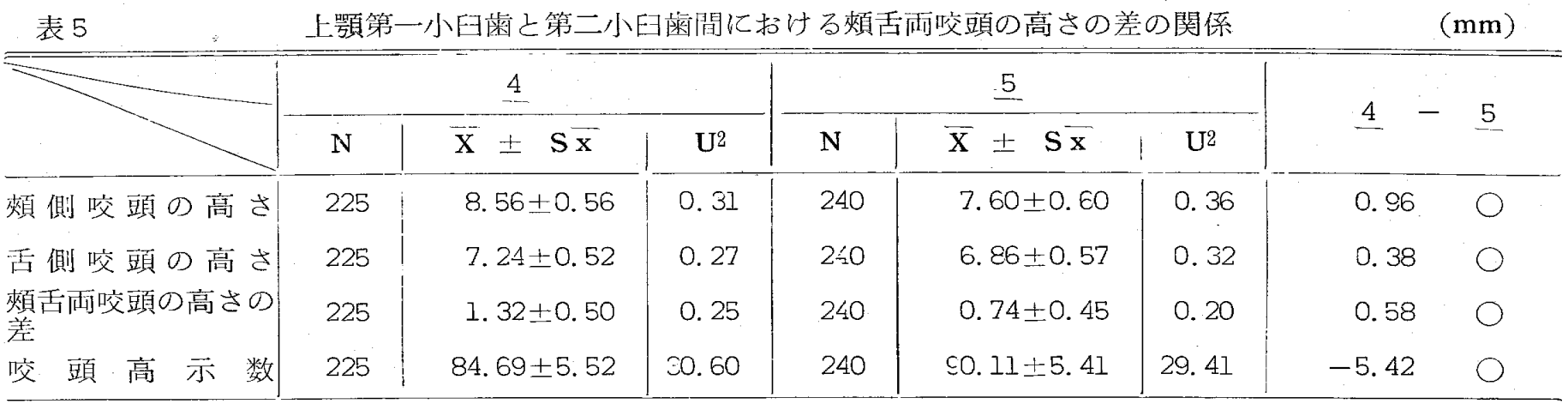

根性のものは不完全分岐根が26.2\%，完全分波根が16.5 \%で常わせて $42.7 \%$ であって，三根性のものはわずかに $0.2 \%$ 認められた。第二小曰耑ではは単根が $96 \%$ で大部 分を示し，二根性の屯のはわずかに $4 \%$ で，そのうち完

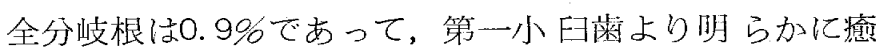
合傾问にあることを認めた。

7 宷根に抢ける溝の状態
前述の米根数に抢ける二根性より単根性への移行型之 して, 蒾根の近遠心唡面に深い縦溝が認められることが ある。したがって兩者と屯单根歯のみについて，その啮 の状態を調查したところ, 表 7 に示すごとく第一小罒柬 ではすべての歯に溝がみられ，しかも近遠心両面ともに 清の存在を認めるものが約70.6\%で，近心のみに存在す るものが29.4\%であって，溝は一般に近心面のほうが遠 
上顎小曰歯の㐘根数についての出現頻度

$(\%)$

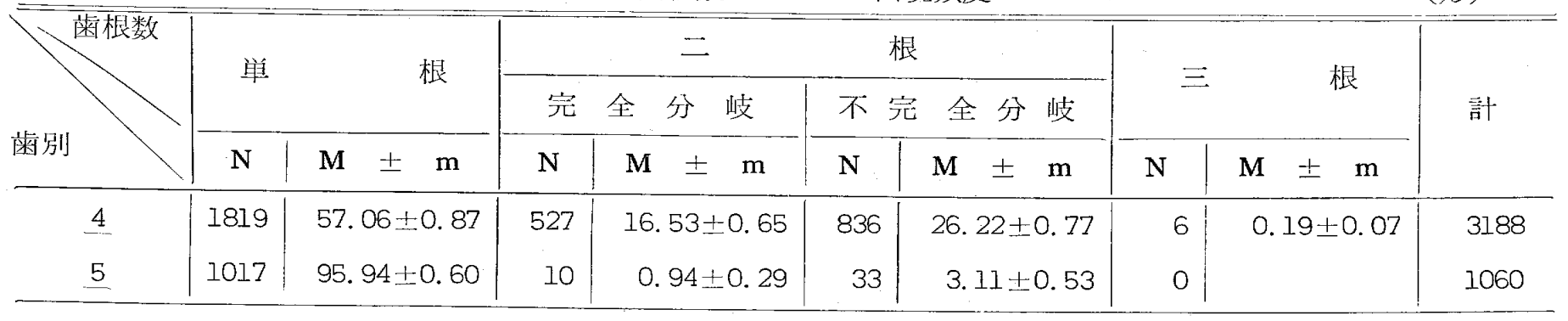

心面より強く出現するような傾向にある。第二小四歯は 近遠心両面之もに存在するあのが62.2\%で，第一小歯 上りもその出現頻度は減少して打り，しかも政は浅くな っている. 次に遠心面にみられるものが33.8\%で, 近心 面のみにみられるすのはなく，第一小四歯とは反対に近
心面より正心面のほうに溝が出現するようである。ま た両面ともに溝が認められないものが $4 \%$ あり，概して 第二小臼歯よりあ第一小臼歯が同じ単根性であっても二 根性に近ずく傾向を示している。

上係小曰歯歯根の溝の出現頻度 $(\%)$

(但し単根崡のみについての調査)

\begin{tabular}{|c|c|c|c|c|c|c|c|c|c|}
\hline & \multicolumn{2}{|c|}{$\begin{array}{l}\text { 近心面のみに瑇があ } \\
\text { るも }\end{array}$} & \multicolumn{2}{|c|}{$\begin{array}{l}\text { 遠心面のみに溝があ } \\
\text { るも }\end{array}$} & \multicolumn{2}{|c|}{$\begin{array}{l}\text { 近遠心両面に满があ } \\
\text { るの }\end{array}$} & \multicolumn{2}{|c|}{$\begin{array}{l}\text { 溝はなく両面とむに } \\
\text { 平坦なものの }\end{array}$} & \multirow{2}{*}{ 計 } \\
\hline & $\mathbf{N}$ & $\mathrm{M} \pm \mathrm{m}$ & $\mathbf{N}$ & $\pm \mathrm{m}$ & $\mathrm{N}$ & $\mathrm{M} \pm \mathrm{m}$ & $\mathrm{N}$ & $\mathbf{M} \pm \mathrm{m}$ & \\
\hline 4 & 535 & $29.41 \pm 1.06$ & 0 & & 1284 & $70.59 \pm 1.06$ & 0 & & 1819 \\
\hline 5 & 0 & & 344 & $33.82 \pm 1.48$ & 633 & $62.24 \pm 1.52$ & 40 & $3.93 \pm 0.60$ & 1017 \\
\hline
\end{tabular}

表 8

上顎小四歯頓側咬頭頂の位置之咬合面清各形態之の関連性

\begin{tabular}{r|r|r|r|r|r|r|r|r|r|r|r}
\hline & N & M I & M II & M II & C I & C II & C III & D I & D II & D III & $\mathrm{X}^{2}$-test \\
\hline 4 & 3188 & $1.13 \%$ & 1.10 & 0 & 4.49 & 8.85 & 3.14 & 28.76 & 44.95 & 7.59 & 62.490 \\
\hline & 1060 & $1.31 \%$ & 11.51 & 16.13 & 2.55 & 23.87 & 37.64 & 0.28 & 2.55 & 4.15 & 0.96 \\
\hline
\end{tabular}

表 9

上紫小曰歯舌侧咬頭頂の位置之咬合面清各形態との関連性

\begin{tabular}{c|c|c|c|c|c|c|c|c|c|c|c}
\hline & N & M I & M II & M III & C I & C II & C III & D I & D II & D III & X $^{2}-$ test \\
\hline 4 & 3188 & $31.56 \%$ & 49.56 & 9.22 & 2.82 & 5.33 & 1.51 & & & & $10.19 \Delta$ \\
\hline & 1060 & $2.83 \%$ & 25.75 & 40.00 & 1.23 & 10.94 & 16.13 & 0.09 & 1.23 & 1.79 & 0.24 \\
\hline
\end{tabular}

8 咬合面溝之煩側咬頭頂之の関連性

前述の咬合面溝の各型上煩側咬頭頂の位害的関戛性を $\chi^{2}$-Test を行なった結果は表 8 の゙こくである。すな わち第一小臼歯は I\%以下で有意差を示し，両者問では 充分に関連性があるものと考えられるが，第二小四歯に 执いては有意性は認められず，したがって関連性がある とは断定できない，ようするに第二小曰歯では䪿側咬頭 頂の位置に対して咬合面涿の状態はそれぞれ独立して別 個に変化しているもののように考えられる。

9 咬合面瑇之舌側咬頭頂の位置之の関連性.

表 9 にみられるごよく，第一小臼歯は5\%以下の有意 差を示し，第二小曰粜では有意差は認められず，前記同
様闭者間に関連性がないようである。

10 咬合面瑇之歯根分岐状態之の関連性

咬合面瑇の状態之歯根数の関係については同じく $x^{2}-$ Test を行なった結果，表10にみられるごとく第一抢よ び第二小罒歯ともにっ\%以下の有意差をもって関連性の あることが認められた。すなわち䨑根数の変化に対して 咬合面溝すをれに応じた形態を示すものと考えられる。

11 咬合百の各部計測值による咬頭頂の位置

1）第一小围菊之第二小曰蒾との比較

咬合面各部の計測を調査方法の項で記述したごとく行 なったところ, 表11のように，第一小四歯では煩側咬頭 頂之近心頰側隅的部間の距離 (A) は頓側咬頭頂之遠心 
ヒトの上顎小曰歯の形態, とくに菡冠と菡根との関係について

表10

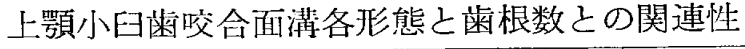

\begin{tabular}{|c|c|c|c|c|c|c|c|c|c|c|c|}
\hline & $\mathbf{N}$ & I 3 & I 2 & I I & II 3 & II 2 & II I & III 3 & III 2 & IIII & $\mathrm{X}^{2}$ - test \\
\hline$\underline{4}$ & 3188 & $0.09 \%$ & 15.09 & 19. 20 & 0.09 & 24.15 & 30.65 & 0 & 3.51 & 7. 21 & $17.41 \bigcirc$ \\
\hline$\underline{5}$ & 1060 & $0 \%$ & 0.75 & 3. 40 & 0 & 2.08 & 35.85 & 0 & 1.23 & 56.70 & $27.20 \bigcirc$ \\
\hline
\end{tabular}

煩側隅角部間の距離（B）よりあ長く，舌側咬頭頂之近 心煩側隅角部間の距離（D） は舌側咬頭頂之遠心煩側隅 角部間の距離 (C) よりも短かく, 煩側咬頭頂は遠心に 舌側咬頭頂は近心にそれぞれ偏位していることが立証さ れる。

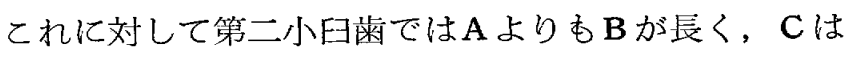
Dよりわずかに長い．したがって煩側咬頭頂は第一小曰 歯之は反対に近心側に偏位し，また舌側咬頭頂も近心側 に偏位しているが，第一小曰歯ほどではなくほとんど煩 舌的正中線に近い位置にある。

次に煩舌両咬頭頂間の距離 $(\mathrm{E})$ ）煩側の近遠心両隅 角間の距離 $(\mathrm{F})$ は第一小䍘で $\mathrm{E}$ が長く, 第二小曰歯 ではほとんど同じくらいか，あるいはわずかに Fが長 く，第二小曰歯は第一小曰歯に比べて頼舌両咬頭間が相 接近してくる傾向にあり，両歯間の特徽的な差異が認め られる。

さて以上の各計測平均值にて賽舌咬頭頂の位置的関係 を示す模型図を作成すると図3のようになる，すなわち 近遠心隅角を貫るた線を基準とし，乙れに対する直角二 等分線を仮に頬舌的中軸線としたところ，第一小臼歯は 甚だしく非対称的な様相をしており，第二小臼歯ではそ
図 3 上顎小臼霜の咬合面外形の比較模型

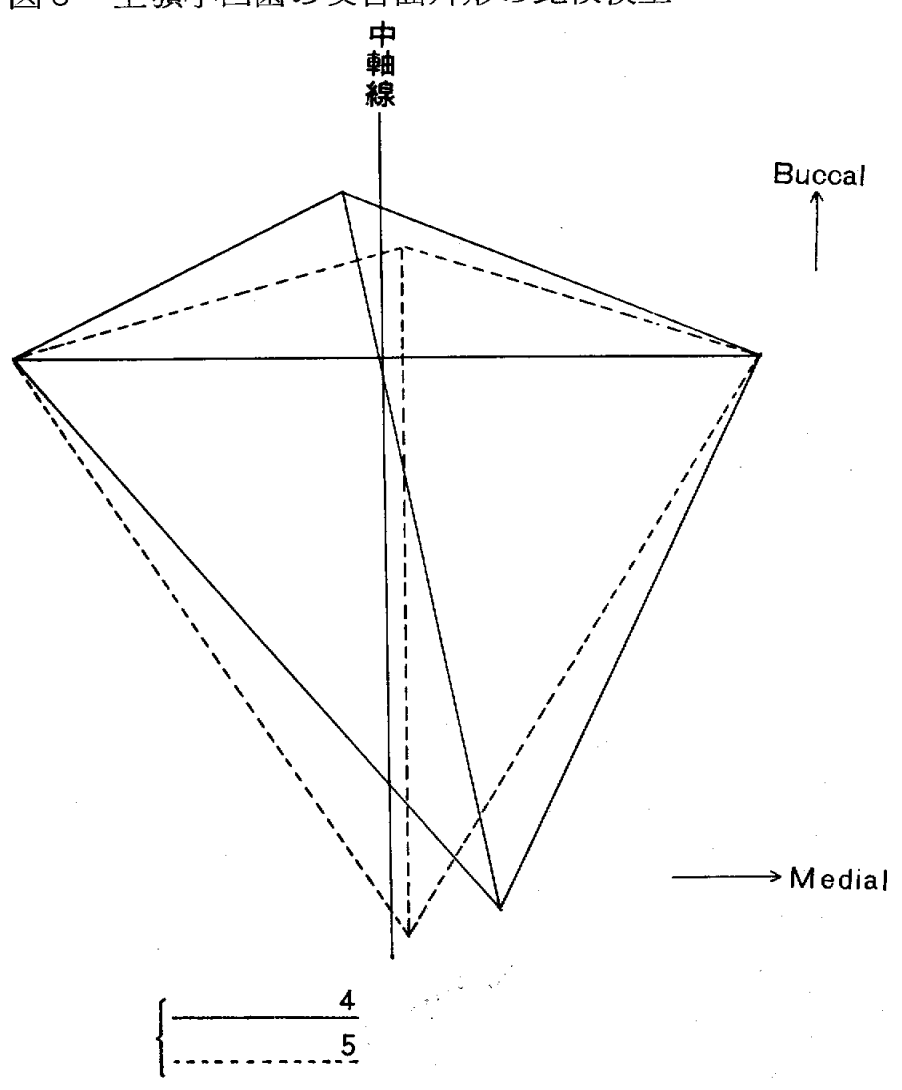
表11 上顎小曰歯歯冠咬合面各部の計測成績

(単位mm)

\begin{tabular}{|c|c|c|c|c|c|c|c|c|c|}
\hline & \multicolumn{4}{|c|}{4} & \multicolumn{3}{|c|}{$\underline{5}$} & \multirow{2}{*}{\multicolumn{2}{|c|}{$4-5$}} \\
\hline & $\mathbf{N}$ & $\overline{\mathrm{x}}$ & $\pm s \bar{x}$ & $\mathrm{U}^{2}$ & $\mathrm{~N}$ & $\bar{x} \pm s \bar{x}$ & $\mathrm{U}^{2}$ & & \\
\hline A & 122 & & $3.66 \pm 0.39$ & 0.15 & 40 & $2.94 \pm 0.32$ & 0.11 & 0.72 & 0 \\
\hline B & 122 & & $2.97 \pm 0.37$ & 0.14 & 40 & $3.25 \pm 0.32$ & 0.10 & -0.28 & 0 \\
\hline C & 122 & & $6.13 \pm 0.55$ & 0. 30 & 40 & $5.95 \pm 0.49$ & 0.25 & 0.18 & \\
\hline D & 122 & & 5. $24 \pm 0.52$ & 0.27 & 40 & $5.80 \pm 0.53$ & 0.29 & -0.56 & $\bigcirc$ \\
\hline $\mathrm{E}$ & 122 & & $6.25 \pm 0.46$ & 0.21 & 40 & $5.92 \pm 0.46$ & 0.21 & 0.33 & $\bigcirc$ \\
\hline $\mathbf{F}$ & 122 & & $5.94 \pm 0.51$ & 0.27 & 40 & $5.95 \pm 0.55$ & 0.31 & -0.01 & \\
\hline
\end{tabular}

の位置が比較的対称的で両者間に差買が認められる.

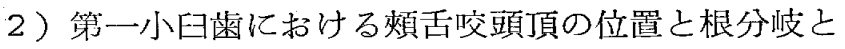
の関係

第一小四歯に沶ける霜根の分岐状態すなわち完全二根 分岐，不完全二根分岐および単根の各曾についての咬合
面各部の計測成績は表12に示すと抢りである。すなわち

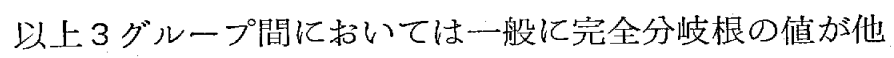
の 2 グループより大きく, 特に A は単根の值, また $\mathrm{E}$ 不完全分岐根の值より著しく大きいが，B は単根の值が 大きくなっている，次に不安全分岐根との間ではそれほ 
どはっきりした差は認められないが，Aは不完全分岐根 ，B弾根がそれぞ机著しく大きくなっている，すなわ ち同じ第一小歯のなかでも歯根の分岐状態によって 差がみられ，㥧側咬頭頂は単根ほど煩舌的中軸線に接近 する傾向がある。

これらろグループの各平均值にて模型図を描いたのが 四 4である。乙れによってあわかるように完全分肢根の 歯では煩舌的中軸線に対して煩側咬頭は遠心に著しく片 より，不完全分岐根の菌に次ぎ単根歯が最む中軸線に近 い位置にあり，また舌側咬頭は類側ほどふぞろいではな く大差ない. このような咬頭頂の変異からみると単根性 歯は第二小禿にかなり接近した形態傾向を示している ともいえる。

\section{総括ならびに考察}

人の上顎小臼雨纣代生歯群の最後方に位置し，特に第 二小曰歯については Bolk や藤田12)が述べているように 退化の傾向が認められる菡である。.今回わたしは上顎小 曰崡の歯冠ならびに歯根形態を抢のおのその計測值とあ わせて調査し，さらに第一扔よび第二小臼歯を比較する ことによって，その退化の状態を察知し得るもの之考 え，また各調查項目間の相互関係をみることによって， 人の上顎小曰歯の形態的概念を種々なる観点より検討し 得たので，総括的に考察を加えながら述べことにす る.

表12 上顎第一小曰蒌の歯根分肢状態による咬合面各部の計測成績

\begin{tabular}{|c|c|c|c|c|c|c|}
\hline & \multicolumn{2}{|c|}{ 完全分岐根（N=39） } & \multicolumn{2}{|c|}{ 不完全分岐根 $(\mathrm{N}=40)$} & \multicolumn{2}{|c|}{ 単 根 $(\mathrm{N}=43)$} \\
\hline & $\bar{x} \pm s \bar{x}$ & $\mathrm{U}^{2}$ & $\bar{x} \pm s \bar{x}$ & $\mathrm{U}^{2}$ & $\bar{x} \pm s \bar{x}$ & $\mathrm{U}^{2}$ \\
\hline A & $3.84 \pm 0.44$ & 0.20 & $3.69 \pm 0.33$ & 0.11 & $3.49 \pm 0.32$ & 0.10 \\
\hline B & $2.96 \pm 0.33$ & 0.11 & $2.84 \pm 0.36$ & 0.13 & $3.14 \pm 0.35$ & 0.13 \\
\hline $\mathrm{C}$ & $6.25 \pm 0.50$ & 0.26 & $6.09 \pm 0.52$ & 0.28 & $6.10 \pm 0.56$ & 0.32 \\
\hline $\mathrm{D}$ & $5.36 \pm 0.56$ & 0.32 & $5.22 \pm 0.41$ & 0.18 & $5.19 \pm 0.54$ & 0.30 \\
\hline $\mathrm{E}$ & $6.37 \pm 0.49$ & 0.25 & $6.14 \pm 0.39$ & 0.15 & $6.25 \pm 0.44$ & 0.19 \\
\hline F & $6.06 \pm 0.53$ & 0.29 & $5.88 \pm 0.49$ & 0.24 & $5.89 \pm 0.50$ & 0.25 \\
\hline
\end{tabular}

㐘冠の大きさについて

歯冠の高さ，幅抢よび厚さの計測值より，第一小正歯 が第二小正よりあ明らかに大きいととを示して怙り， 大きさは第一より第二小罒霜へと縮小化の傾向にあると とが認められる。このととは歯冠の幅と厚さの和を求め 比較した結果においてあ第一小四電が著明に大きいとと

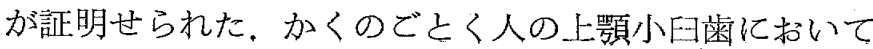

図4 上顎第一小四歯に㧈ける歯根の分岐状態による 咬合面外形の比較模型図
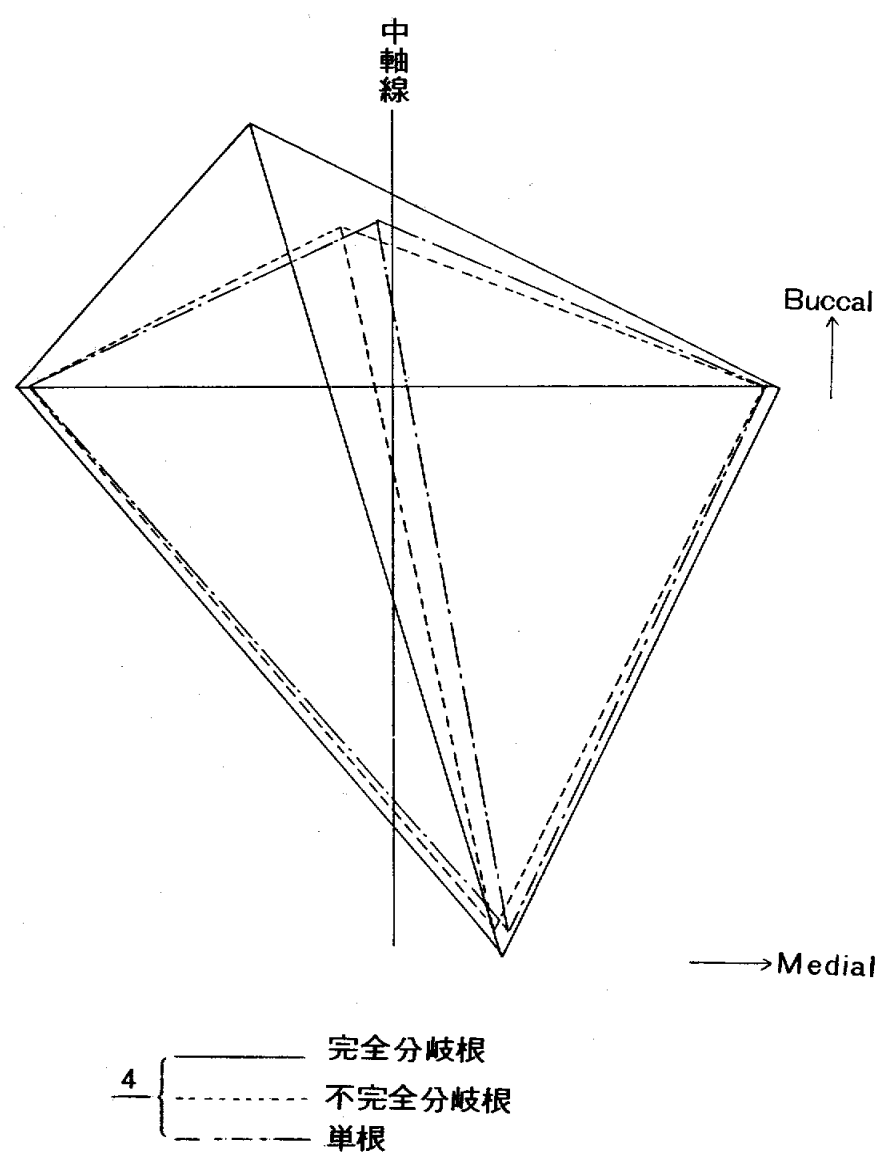
し，いわゆる退化的傾向に方ることを允分証明している そのである。

また歯冠幅厚示数では第一小臼歯が第二小臼蒾よりも 大きい值を示して抢り，第二小曰霜はよりいっそう近遠 心的に压平されている。乙れは山田2）らの調査成績にお いてあ同様の傾向が認められるところであって，永久歯 上りも原始的な形態といわれている乳歯，特に乳臼歯に おいても同様の傾向が認められるところであり，永久荘 よりも原始的な形態といわれている，乳㐘，特化乳臼歯 においては比較的頓舌的な压縮が強くみられるが．第二 小臼歯においては反刘に近遠心的に圧絎されているとい うことはややはり菌の進化にともなう退化現象と推察し ている.

\section{菌冠の形態之相互の関係}

上顎小臼に㧍ける咬合面溝の形態は図 2 に示す第 I 型 が最す基本的な形態で，それが単純化してくるにしたが って遠心側の横副溝や舌側副溝などが消失し，最後には 中心溝のみで副清の一部が痕跡的に残る程度で，II型， III型へ之変化してくるものである。したがって今回の成 績に扔いても，第一小歯では而型に次ぎ I 型が多い

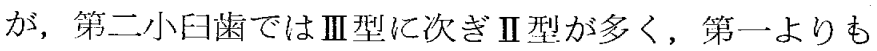
符二小曰歯がより単調化しているととが認められる。山 田らは $\mathbf{A}$ 型より $\mathbf{E}$ 型まで五段階に分類し，その $\mathbf{A}$ 型がわ たしのI型に相当するものであって，A型が第一小臼雨 で50\%以上を示し，恥りの高頻度を得て扔るのに対

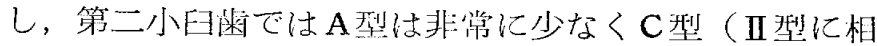
当）が過半数を占め，ほぼ同様な傾向を示しているが，

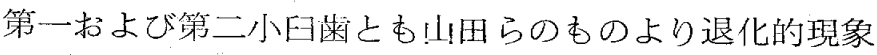
が強く現われているようである。

咬合面溝が単調化しているのは副溝の消失によるあの であり，酒井7）らの報告の中で横㨽瑇の出現率は遠心側

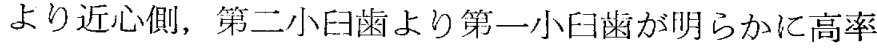
であると还べている。すなわち上顎小臼荬では遠心側よ り消失していることになり，わたしの今回の成績むこれ を裹づけるあのである。

次に㚘貢画咬頭頂の位置を肉眼的に観察した結果より 判断する之，第一小田歯の煩側咬頭頂は遠心側に舌側穴 頭頂は近心側に偏位して招り，第二小臼歯では槙側咬頭 頂は中央に舌側咬頭頂は近心側に位置して, 両歯間に相 異がみら机た。

そこで咬頭頂の位置之咬合面清の形態を $\chi^{2}$-Test に よって，その関連性を調べてみると，第一小四㐘では有 意性が認められるむ，第二小四歯に执いては全く認めら れないのである。すなわち第一小四歯では比較的に小曰
㐘の甚本的な形態を保持して，安定した状態を示してい るが，第二小四菌になるとその北態に変異形が出現し， しかも咬合面满および唯頭頂の位置についてはそれぞれ 独自に变化するためであると考えられる，要するに形態 に不安定さが生ずる結果にほかならない．

煩側咬頭之舌側咬頭の高さを第一抢よび第二小臼歯に ついてそれぞれを比較検討してみると，一般に第二小曰 料に打ける両咬頭の高さは相接近し，両者間の差は少な く，上条の示数值でみた報告とほぼ同様な結果を得た。 また藤田は第一小囦柬に沶ける両咬頭の高さの差が 1.3 $\mathrm{mm}$ に対し，第二小四歯は0.4mm と著しく差が縮まって いると述べている，そこで両㕮頭の高さの差の平均值を みたところ第一小臼電が $1.32 \mathrm{~mm}$ ，第二小曰雪が 0.74 $\mathrm{mm}$ で, 差の分布状態は表13のごとくで，また分布曲線 では図 5 のごとくになって，第一小曰歯では正規分布の 態状を示し, 第二小四菊では左端より右万向への下降線 を描き，実際の平均值よりさらに小さくなることが考え られ，两咬頭間にほとんど高さの差はないといっても過 言ではない，図6は第一および第二小四䨑を隣接面よ り観察した模型図で，咬頭の高さを比較したものであ る.

棶根の形態ならびに歯冠形態との関係

歯根数は第一小罒歯では二根性のものが比較的多く認 められるが第二小曰歯に扔いてはほとんど一根性であ り,さらには一根性の菌でも第一小罒歯は歯根の近遠心 面に深い縦瑇が走っているのに，第二小歯ではその溝 が不鮮明となり，あるいは全く認められないあの屯あ る. かくのごとく歯根は第一小臼歯の分岐傾向より第二 小曰歯の癒合ないし単根化の傾向が認められる.

さて類人猿や狭鼻猿類の上顎小曰㐘に执いては歯根数 は三根性であるが，人類に括いては三根性の歯は第一小 臼㐘に抢いてわずかに認められ，今回の諷査では $0.2 \%$

図 5 上顎小臼崡に抢ける頓舌両咬頭の高さの差を示 守分布曲線

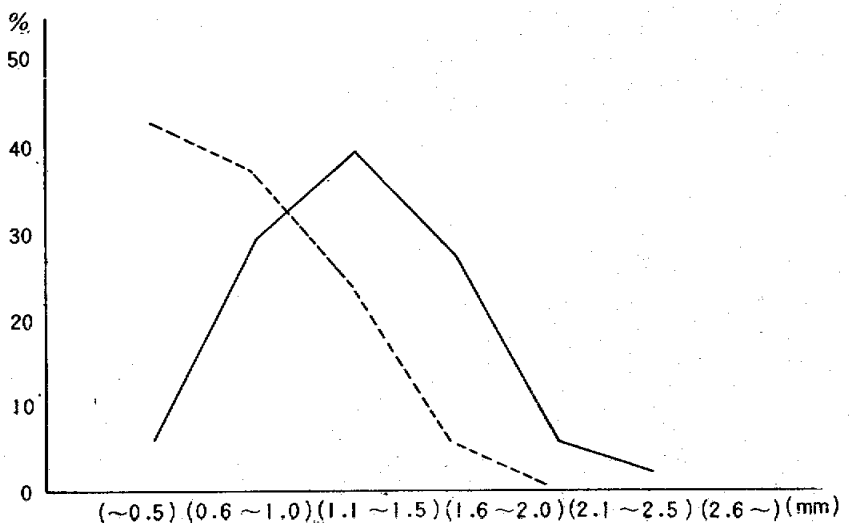


図 6 上頡小曰歯の煩舌㕮頭頂の高さを示す模型図

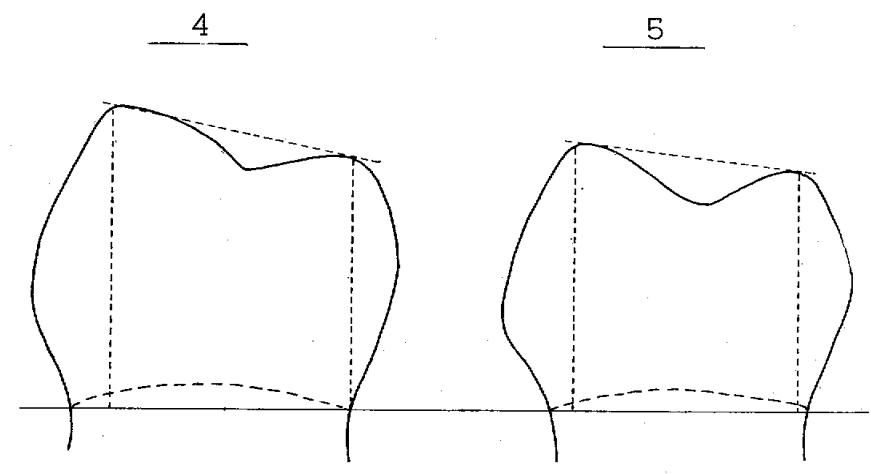

に過ざず，また日本人についての他の調査でも奥村11)は $5.6 \%$, 藤田 ${ }^{17)}$ は0.5\%, 岡本は0.9\%と少なく, 欧米人 については Hillebrand は2.2\%, Churchill は $1.2 \%$,

Visser は3.0\%と報告し，さらに，Hillebrand は Bantu 族にて6.1\%とかなり多くの出現頻度があると報告して いる。一方上顠小四菌の先行乳菡に扔いては第一捄よび 第二乳臼歯之も三根性であって 類人猿などと同様であ る.

以上のような事㥶から人の_上顎小曰雪は三根性より二 根性へ上推移し，さらに現在ではそれが単根性へ之進み

表13

上顎小曰断賽側咬頭と舌側咬頭の高さの差の分布状態

\begin{tabular}{|c|c|c|c|c|c|c|}
\hline 高 & の & 差（mm） & & 4 & \multicolumn{2}{|c|}{$\underline{5}$} \\
\hline & 0 & $\sim 0.5$ & 12 & $(5.3 \%)$ & 94 & $(39.2 \%)$ \\
\hline & 0.6 & $\sim 1.0$ & 60 & $(26.796)$ & 82 & $(34.2 \%)$ \\
\hline & 1.1 & $\sim 1.5$ & 81 & $(36.0 \%)$ & 52 & $(21.7 \%)$ \\
\hline & 1.6 & $\sim 2.0$ & 56 & $(24.996)$ & 12 & $(5.0 \%)$ \\
\hline & 2.1 & $\sim 2.5$ & 12 & $(5.3 \%)$ & 0 & \\
\hline & 2.6 & $\sim$ & 4 & $(1.8 \%)$ & 0 & \\
\hline & & 計 & 225 & & 240 & \\
\hline
\end{tabular}

つつあると考えられる。しかむ単根化への現象はすでに

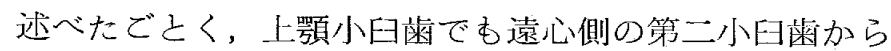
進行しつつある。しかしながらこのような菌根数減少の 傾向は永久歯にのみいえることで，乳㐘はいまだこのよ うな傾向を示さず，現在も三根性を保持しているすので ある。したがって乳苗やあるいは永久蒾で屯三根性の歯 を持っているものは原始的形態を示しているものという ととができる。

また咬合面满上霜根数との関係すなわち咬合面灌の変 異に応じて歯根数が変化するかという点に関しては，第 一抢よび第二小四歯上も関連性が認められ，咬合面溝の 退化にしたがって歯根数も二根より単根へと変っている ようである。第一小臼歯に扔いては咬合面㴗の形態も。 また歯根も比較的変異が少ない，第二小臼歯では著明な 退化的現象を示している.

咬合面の各部計測值による煩舌咬頭頂の位置的比较 第一小臼歯と第二小臼歯咬合面各部の計測值によって 作図した図了をみると，両者間には明らかな差異が認め られる，すなわち咬合面の煩舌的中軸線に対して，第二 小曰菌煩舌側咬頭頂は比較的対称的に位置しているが, 第一小目宩はかなり非対泉的に煩側咬頭頂は遠心側に，
舌側咬頭頂は近心側に偏位して抢り，今回肉眼的に雨咬 頭頂の位置を観察した結果とほぼ一致している，従来の 成書に記されている上顎第一小四歯の咬合面観に求汀る 䅡側遠心隅角よりも鋭く突出しているという点について はこの図に执いても明らかに認められるところである が，頓側咬頭頂が遠心に偏位しており，その結果煩側の 遠心咬合縁が近心咬合縁より短かい点については明確に 記載されていない，しかしてのような事実があるからこ そ当然湾曲徽が他の菊とは全く逆の状態を示していると いうことがいえる。さらに第二小臼雨は比較的対称形を 示しているため，煩側の交頭頂之近遠心両隅角間の距離 にほとえぞ差がなく，湾曲徽は認められない．

第一小四歯に打ける歯根の分岐状態を三群に分類し， それぞれの咬合面各部計測值に上って作図した咬合面外 形之比較するに，図４のでとく三群の間には特徽ある差 異がみられるのである。すなわち完全分收根の畨は他の 二群に比べて最も大きく，しかも煩側咬頭頂ば最も遠心 に编位して，搷舌的中軸線に対して著しく非刘称的な状 態を示している，不完全分岐根招よび単根菌の間ではそ れほど大きな差異は認められないが，頓側咬頭頂は歯根 が癒合し単根化するにしたがって，次第に中軸線に近づ 
き，対称的な形態を示すようになり，第二小田歯の形態 に類似してくる．乙のように同じ第一小臼歯においても 䨑根の分岐状態によって咬合面の外形が変化してくると いうことは，現在まで全く述へられていないととであ る：要するに歯根が觝合傾向を示すのは前述したでとく 退化的傾向の表現に他ならないのであって, これに応じ 歯冠部にあ変化が生じることは当然考えられることであ る.第一小臼歯では完全分岐根が最も基本的な形態であ って，これより単根性の函ほど咬合面形態が退化し，さ らに第二小歯へ之退化の傾向が強く現わ机てくるもの である。

上顎小曰歯の退化的傾向について人の上顎小曰歯は現 在第二小臼歯に打いて退化的傾向を示しているといわれ ている. Bolk の Terminale Reduktion の説に従えば 雪は䊝列全体に平等に現われるのではなく，乳崡列およ び代生歯列の未端部より退化し，大臼歯は本来乳歯であ るため，乳霜列の末端部にある智歯から退化がみられ， 代生䨑列は末端部の第二小四雪より退化がみられるとし ている．また藤田12,17)はこの考え方をさらに発展させ， 哺乳類の雪は切歯列， 曰歯列のおの扔のにおいて，その 両端から退化するという説を立て, 人類では上㖽切䨑, 上下顎曰䨑列のそ机ぞれ遠心側より退化するが下顎切歯 は特殊な退化が行なわれるすのとしている。

このような系統発生学的な見解任立って考えるなら
ば，第二小曰歯は智歯および上顎側切歯に次ぎ退化的傾 向が強く現われ，ついには欠如をみる場合ああるという ことが当然なととと推察される。しかしながら退化現象 として最終的な形を取るものが欠如例であって, 歯の形 態の上で退化的現象として認められるものは欠如に至る までの変異過程である。そこで今回の調査結果より第一 小曰霜に対し第二小曰菌がいかなる点で退化的傾向を示 しているかといった点を考えてみよう.

まず大きさの縮少化であるが，雪の計測值によっても 明らかに差がでている．藤田4) は歯の退化指数なるもの を提唱し，尾崎 6 ) はそ扎基いて日本人の雪の退化示数 を発表している．すなわち退化示数（R）とはある退化 形の歯の測度 (a ) が同一歯種に属する基本型の測度 (A) に対してどれだけの割合であるかを表現したもの で, $\mathbf{R}=\frac{\mathbf{a}}{\mathrm{A}} \times 100$ によって得られた数值である。これ

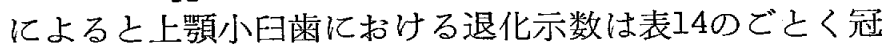
長の短縮が最大で, 次に冠幅, 冠厚の順となっている. 藤田や尾崎の調査に招いても同様で, 特に尾崎は根長, 全長怙よび歯冠面樻についても退化示数を算出し，根長 のみ示数が上昇し，その他はすべて下降して扣り根長以 外はすべて退化が現われているといっている，したがっ て上顎第二小曰䨑はその大きさでは冠長, 冠幅, 冠厚の 順序で綰少し退化が進んでるいともの考えられる。

その他退化的傾向として形態の単調化が挙げられ, 㐘 表14 上頸小目爾の退化示数值比較

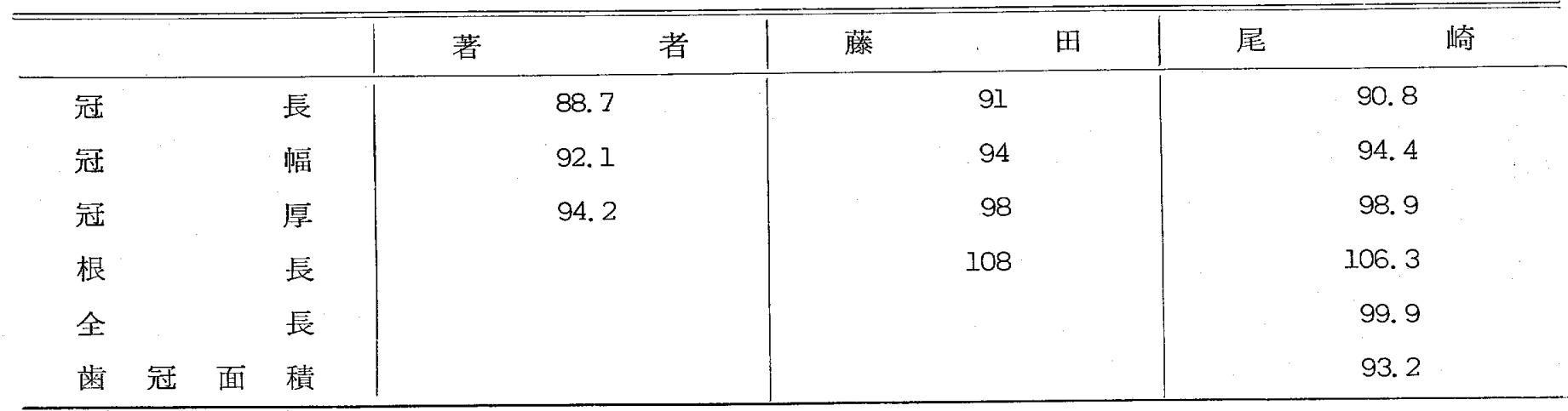

冠咬合面について, 溝は第一小曰雬の基本型上り第二小 且䨑では副溝が消失し，単純型に変り，また煩舌両咬 頭, 特に煩側咬頭頂が顂舌的中軸線に著しく接近し, 煩 側の近遠心隅角部がほとんど同じ角度を示している。 丸味を示し，第一小臼歯のように遠心隅角部の強い突出 は示さなくなっている。歯根においてす第一小罒㐘では 二根性がかなり認められ，少数ではあるが原始形の三根 性屯認められたが，第二小四歯ではほとんど単根性であ る。このように第二小曰霜は歯冠抢よび歯根ともにかな
りの退化傾向が認められ，上顎小曰柬ではその遠心端よ り退化しているここは明らかである。

Garn18） らは第三大曰歯の久如（退化）之他の電の形 質之の相関について研究し, 埴原22 は上顝側切歯につい て同様の研究を行ない，雪の進化は特定の形質汇独立に 起るものではなく，大なり小なり他の諸形質の変化をと あなうことは明らかであると述へ，退化霜がある場合は 他の雨屯小さくなっていることを確認している，私はそ の点については調查し得なかったが, 同一の上須小曰歯 
自体に执いて退化的要素を含む形質相互間には関連性を 持っているものと，明らかな関連を持たないすのがあ り, 特に咬合面溝の変化は菡根の癒合傾向に相応じ, ま た咬頭頂の変化も雬根の癒合傾向之関係づけられるもの と推察した。

\section{結 論}

人の上顎小四歯の形態ならびに各形態相互間の関連性 を調査検討し，かつまた歯冠の大きさおよび咬合面各部 の計測を行ない次のごとき結論を得た

\section{1. 歯冠の大きさ}

第一小四歯は第二小四歯よりも，すべての径に扔いて 著明に大であり，特に歯冠幅が最あ大きな差を示した。 また退化示数によると冠長, 冠幅, 冠厚の順に退化がタ られた。

\section{2 . 㚘頁側咬頭と舌側咬頭の高さ}

両咬頭亡屯第一小曰歯がまさっていた，両咬頭の高さ の差は第一小囦㐘がまさり，第二小罒歯では著しく接近 していた。

\section{3. 菡根}

第二小曰歯では大部分が単根性であるが，第一小四歯 では二根ないし三根性のあのがあり，単根性でも根の近 遠心両面に縦溝がみられ，二根性の痕跡を示す屯のが多 かった，系統発生学的に三根性より二根性そして単根性 に向いつつあることが観察された。

\section{4. 咬合面溝の形態}

第一小罒歯では基本的な形態を保持しているものが多 く，第二小曰歯では副溝などが消失した单調な形態をし たものが多かった。また咬合面溝は歯根分肢の状態と深 い関連性が認められた。

\section{5 . 煩舌両咬頭頂の位置}

第一小曰歯に扔いては煩側咬頭頂は遠心側に，舌側咬 頭頂は近心側にそれぞれ偏位し，煩舌的中軸線に対して 甚しく非刘称的であるが，第二小四歯に拀いては両咬頭 頂ともわずかに近心に偏位し，第一小曰来とは異なった 形態を示した。

またこれら咬頭頂の位置と咬合面溝との間に，第一小 四歯では形態的に安定した状態をしているため, 関連性 が認められるが, 第二小因䅈では変暴形を示するのが多 く両者間の関連性は認められなかった。

6. 咬合面各部測定平均值によって作成した模型図に よる比較

頰舌の咬頭頂の位置は第一および第二小罒歯間に明ら かな差異が認められ，肉眼的観察に近侦した結果を得
た。また第一小四歯については歯根の分岐状態によって 三群に分類し比較したところ，単根性の㐘ほど第二小臼 歯の形態に類似し，根の分岐が著明になるほど，大きく なり煩側咬頭頂はより遠心側に偏位し著しく非対称的な 形態を示すようである。

7.以上のような事夷から第二小罒㐘は大きさの縮少 化, 咬合面瑇の形態の単純化, 歯根数の減少傾向および 煩舌咬頭頂の対称的な形態を示すといった，いわゆる退 化的現象が多く認められた。

稿を終るに臨み御指導御校閲を賜った三枝教授ならび に山田教授に深甚なる感謝の意を捧げるとともに，種々 御助言いただいた教室員に深く感謝致します。

\section{文献}

1。鹿井克己；四歯咬合面における裂溝の形態について : 熊本医会誌, 3I (補 3)，463～496, (1957).

2. 山田 博, 䱏石洋已, 中川三省; 人類小田蒾蒾冠の 形態学的研究 : 九州㐘会誌, $17(3,4), 1 \sim 13$, (1964).

3. 武久 滋; 米白人雪牙と日本人歯牙の人類学的なら びに形態学的比較研究 : 東 京歯大解剖 学教 室業績 集，4，I〜41，(1957).

4. 藤田恒太郎; 歯の退化指数について：解剖学雑誌， 25 ( 4 ), 196, (1950).

5. 藤田恒太郎; 米の計測規準について：人類学雑誌, 61 ( I ), 27 32, (1949).

6. 尾崎 公; 日本人の柬の退化示数 : 解剖学雑誌, 35 (5)，563〜577，(1960).

7. 酒井琢朗, 佐々木泉, 花村肇; 日本人歯牙のエナメ ル・ゾウゲ境についての形態学的研究. III.上顎小 曰歯：人類学雑誌, 75 ( 5 ), 207〜223, (1967).

8.中川三省, 鮕石洋己, 杉山正博, 陶山信; 人の歯の 過剩㐘根について：九州歯会誌，23（4)，498〜 505, (1969).

9. 埴原和郎; 日本人执よび日米混血児乳歯の研究, ( 4) 上買乳田歯：人類学雑誌， 65 (2), 67〜87, (1956).

10. 飯島直寿; 三根を有する上顎第一小罒歯の臨休例： 歯科月報, 22 (3)，94～95，(1953).

11. 奥村鶴吉 ; 小曰蒾の猴徵 : 歯科学報, $19(9), 1$ $\sim 7$, (1914).

12. 藤田恒太郎; 哺乳類とくに人類の歯の系統発生：解 剖学雑誌, 33 ( 2 ), 89 94, (1958). 
13. 下総高次, 六人部慶夫, 保田和雄; 多根性下顎第一

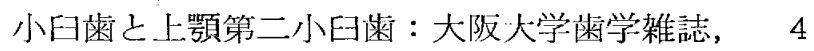
(2), 471 480, (1959).

14. 山田越二, 日本人歯牙の人種解剖学的研究: 日本歯 科学会誌，25（7)，450４81，（8），528～544, (9), 609 640, (10), 710 728, (1932).

15. 藤田宗次; 日本人永久歯の計測学的研究: 人類学人 類遗伝学体質学論文集，19，89～144，(1952).

16. 上條㻾彦; 日本人永久宩解剖学： I 272, 地人書 館 (東京), (1963)。

17. 藤田恒太郎; 歯の解剖学：1１30, 金原出版 (東 京), (1959).

18. Garn. S. M., A. B. Lewis and J. H. Vicinus ; Third molar polymorphism and its significance to genetics: Journal of Dental Research, 42 (6), 1344 1363, (1963).
19. Garn. S. M. and Lewis. A. B. ; Phyogenetic and Intra-Specific Variations in Tooth Sequence Polymorphism: Dental Anthropology, 53 73, Pergamon Press, (1963).

20. Kraus. B. S., Jordan, R. E and Abrams, L. ; Dental Anatomy and Occlusion : $1 \sim 311$, The Williams and Wilkins Company (Baltimore), (1969).

21. Sicher H. ; Oral Anatomy : 217 295, The C. V. Mosby Company (Saint Louis), (1965).

22. 沿原和郎, 増田哲男, 田中武史; 退化歯扔よび過剩 歯の進化学的意義敒関する一考察 : 人類学雑誌， 73 ( 3 ), 72 81, (1965).

23. Bolk L. ; Problem of human dentition: The American Journal of Anatomy, 19, 91 148, (1916). 